\title{
Clinicopathologic features and responses to radiotherapy of myeloid sarcoma
}

\author{
Wan-Yu Chen ${ }^{1,5,7}$, Chun-Wei Wang ${ }^{1,5}$, Chin-Hao Chang ${ }^{2}$, Heng-Hsiu Liư ${ }^{4}$, Keng-Hsueh Lan ${ }^{1,5}$, Jih-Luh Tang ${ }^{3}$, \\ Hwei-Fang Tien ${ }^{3}$, Sung-Hsin Kuo $0^{1,3,5,6^{*}}$ and Ann-Lii Cheng $1,3,5,6$
}

\begin{abstract}
Background: To evaluate clinicopathological features, radiotherapeutic parameters, and their associations with responses to radiotherapy (RT) in patients with myeloid sarcoma (MS).

Methods: We reviewed 20 patients receiving RT for MS lesions (in 43 RT courses) and analyzed the patients' clinicopathologic features and radiotherapeutic parameters, and their associations with complete responses (CR) to RT using Fisher's exact test and univariate logistic regression analysis. Generalized Estimating Equation was used to analyze all 43 irradiated lesions and account for the correlations in RT responses among lesions from the same patient.

Results: We found that the underlying hematological diseases of the evaluated patients were acute myeloid leukemia (AML) in 14 patients (70\%), chronic myeloid leukemia in 4 patients (20\%), myelodysplastic syndrome with AML transformation in one patient (5\%), and de novo MS in one patient (5\%). Most patients (55\%) received RT for MS at the time of relapse following bone marrow transplantation (BMT). The most common cytogenetic abnormality was t(8;21)(q22;q22). The median RT dose of 20 Gy (range 6-35 Gy), administered in 1.5-3.5 Gy fractions, provided a $63 \% \mathrm{CR}$ rate. RT dose, sex, cytogenetics, and bone marrow status at the time of RT had no significant effect on $C R$. Younger age $(<50 y, P=0.06)$, BMT prior to RT $(P=0.05)$, and underlying $A M L(P=0.05)$ were marginally associated with higher CR to RT.
\end{abstract}

Conclusions: Our results indicate that a modest RT dose (20-30 Gy) achieves good local control of MS. Age, previous BMT, and underlying hematologic disease can affect RT response.

Keywords: Chloroma, Granulocytic sarcoma, Myeloid sarcoma, Extramedullary leukemia, Radiotherapy

\section{Introduction}

Myeloid sarcoma (MS), also known as granulocytic sarcoma or chloroma, is a rare clinical condition characterized by aggregation of immature myeloid cells presenting as an extramedullary mass [1]. The most commonly involved sites are the small intestine, bone, skin, and lymph nodes [2]. MS can develop de novo or emerge during the clinical course of acute myeloid leukemia (AML), myeloproliferative disorder (MPD), or myelodysplastic syndrome (MDS). In AML patients, MS might represent the first

\footnotetext{
*Correspondence: shkuo101@ntu.edu.tw

'Division of Radiation Oncology, Department of Oncology, National Taiwan University Hospital and National Taiwan University College of Medicine, Taipei, Taiwan

${ }^{3}$ Department of Internal Medicine, National Taiwan University Hospital and National Taiwan University College of Medicine, Taipei, Taiwan

Full list of author information is available at the end of the article
}

manifestation of AML, predating it by months or years. It can also be the initial presentation of relapse in remission, with or without underlying bone marrow (BM) relapse, with reported incidence of 3-9\% [3,4].

MS can present at various sites of the body resulting in prominent symptoms and signs. Diagnosis of MS requires a high degree of vigilance by physicians. Its optimal treatment remains controversial. Chemotherapy or hematopoietic cell transplantation is often considered the frontline treatment for MS. Radiotherapy (RT) could be reserved for palliation of symptomatic or rapidly progressive lesions $[5,6]$ or as part of a combined modality treatment in conjunction with chemotherapy or hematopoietic cell transplantation. RT is also considered a consolidative treatment for isolated MS without BM involvement, or during BM remission after systemic therapy [7]. However,

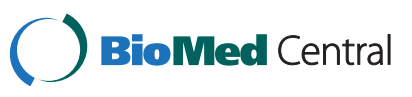


data on outcome from RT in MS is limited and most previous studies are case series reports.

In this study, we investigated the possible underlying predictive factors, including clinicopathologic features and radiotherapeutic parameters, for response to RT in MS patients who received frontline or palliative RT. We evaluated 20 patients and their irradiated lesions, and reviewed responses to RT and RT doses reported in previous studies on MS patients who received frontline or palliative RT.

\section{Patients and methods}

\section{Patients and clinical characteristics}

Twenty consecutive patients with MS who received RT at our institute from 2000 to 2010 were retrospectively reviewed. This restrospective study was approved by institutional review board of National Taiwan University Hospital. Pathologic evaluation of incision biopsy or needle aspiration of these 20 patients demonstrated the histomorphologic features of MS characterized by homogenous malignant infiltrations of immature large cells with ovale and slightly nuclei. Further immunohistochemical studies, including lysozyme and myeloperoxidase (MPO), CD68, and chloroacetate, were used to detect their myeloid origins and exclude lymphoreticular tumors and mesenchymal tumors. The histopathological characteristics and immunohistochemical results of all tumor specimens were independently reviewed by experienced hematopathologists. Cytogenetic studies were also performed. The patients had 43 irradiated lesions. Clinicopathologic features including age, sex, underlying hematologic diseases, MS site for RT, timing of MS emergence, cytogenetics, and radiotherapeutic parameters (including RT dose and fractionation), and responses of the treated lesions to RT were assessed. During the same period, 18 MS patients without RT served as control group.

\section{Radiotherapy}

RT was provided using ${ }^{60}$ Cobalt, 6-10 MV linear accelerators or 9-12 MeV electrons for superficial lesions. The RT field was the gross tumor and a $2-3 \mathrm{~cm}$ margin. Radiation doses ranged from 6 Gy to 35 Gy (median, $20 \mathrm{~Gy}$ ) at a dose per fraction of 1.5-3.5 Gy (median, $2 \mathrm{~Gy}$ ). Twenty-eight lesions (65.2\%) received RT in doses $\geq 20$ Gy. Because various fraction sizes were used, conversion of the total radiation dose to biologically equivalent doses (BED) delivered at 2 Gy per fraction (BED2) were calculated using the linear-quadratic model [6]:

$$
B E D 2(G y)=\frac{n d\left(1+\frac{d}{\alpha / \beta}\right)}{\left(1+\frac{2}{\alpha / \beta}\right)}
$$

where $\mathrm{n}$ is the number of fractions and $\mathrm{d}$ is the dose (Gy) per fraction. An $\alpha / \beta$ ratio of 10 is used for leukemia [7], resulting in a BED2 ranging from 6.5 Gy to 35.9 Gy (median, 20 Gy).

Lesions' initial responses to RT were assessed by physical examination, computed tomography (CT), or magnetic resonance imaging (MRI) within 4 weeks of completion of RT. A complete response (CR) was defined as no evidence of disease and a partial response (PR) as $>50 \%$ regression of all measurable tumor mass. Lesions with $<50 \%$ regression, stable disease (SD), or progression were classified as displaying no response.

\section{Statistical analysis}

Seven of the 20 patients received multiple courses of RT to distinct lesions, resulting in 43 irradiated lesions. Among 7 patients with multiple courses of RT, 2 patients received coinstantaneous irradiation to multiple sites and 5 patients received multiple sequential courses of RT. If a patient received multiple sequential courses of RT, data from the first RT course were used for analysis. Data from one RT site with coinstantaneous irradiations were randomly selected when patients concurrently received RT to multiple sites. Treatment responsesto RT doses (BED), underlying hematologic diseases, age, sex, cytogenetics, bone marrow transplant (BMT) prior to RT, and BM status at the time of RT in MS were correlated. Fisher's exact test was used to evaluate the associations between category variables. Crude odds ratios (OR), 95\% confidence intervals $(\mathrm{CI})$, and $P$-values were calculated using univariate logistic regression analysis. Post-RT overall survival (OS) was calculated using the Kaplan-Meier method.

The Generalized Estimating Equation(GEE) was introduced by Zeger and Liang [8] to cope with clustering data that would otherwise be analyzed using a generalized linear model. GEE has become an essential tool for the analysis of correlated data. In this study, GEE was used to account for correlations in responses to RT among lesions from the same patient. The unit of analysis was the irradiated lesion. All statistical analysis was performed using SAS software (9.2, SAS Institute Cary, NC).

\section{Results}

\section{Clinicopathologic features and survival of MS patients} with RT

We included 20 patients (median age, 45 years old (y), range 4-83 y; 10 men and 10 women) with 43 irradiated lesions in our analyses. The median follow-up time was 4.3 months (range, 0.5-56.7 months). Table 1 displays the clinicopathologic features of the patients and their treated lesions. The underlying hematologic diseases included AML in $14(70 \%)$ patients, chronic myeloid leukemia (CML) in $4(20 \%)$ patients, MDS with AML 
Table 1 Patient characteristics for MS patients with RT

\begin{tabular}{|c|c|c|c|c|c|c|}
\hline $\begin{array}{l}\text { Patient } \\
\text { no. }\end{array}$ & Age & Gender & $\begin{array}{l}\text { Underlying } \\
\text { disease }\end{array}$ & $\begin{array}{l}\text { GS site for } \\
\text { radiotherapy }\end{array}$ & Timing of GS emergence & Cytogenetics \\
\hline 1 & 62 & $\mathrm{~F}$ & AML-M2 & Skin & Relapse after chemotherapy, BM also (+) & Normal \\
\hline 2 & 50 & M & $C M L$ & Anus & CML in blast crisis & $47 X X Y, \operatorname{inv}(11)$ \\
\hline 3 & 83 & M & AML-M4 & Skin & Found at initial presentation with BM (+) & $\mathrm{t}(2 ; 14), \mathrm{NPM}(-), \mathrm{FLT3}(-)$ \\
\hline 4 & 55 & M & AML-M1 & Spinal cord & Relapse after chemotherapy, BM also (+) & $\mathrm{t}(9 ; 22)$ Philadelphia chromosome $(+)$ \\
\hline 5 & 58 & M & AML-M1 & Skin (7 lesions) & Relapse after BMT, BM also (+) & Normal \\
\hline 6 & 6 & $\mathrm{~F}$ & $C M L$ & Bone (right femur) & CML in blast crisis & t(9;22) Philadelphia chromosome $(+)$ \\
\hline 7 & 71 & $\mathrm{~F}$ & MDS- RAEB 2 & Brain & - & Normal \\
\hline \multirow[t]{2}{*}{8} & 41 & F & AML-M2 & Cervix & Relapse after BMT, BM (-) & $\mathrm{t}(8 ; 21)$ \\
\hline & & & & Right breast & Relapse after BMT, BM (-) & \\
\hline \multirow[t]{3}{*}{9} & 42 & M & de novo sarcoma & Right nipple & Found at presentation, BM (-) & Normal \\
\hline & & & & Brain & Relapse after chemotherapy, BM also (+) & \\
\hline & & & & Paranasosinus & Relapse after chemotherapy, BM also (+) & \\
\hline 10 & 56 & M & CML & Spinal cord & CML in blast crisis & Normal \\
\hline 11 & 22 & M & AML-M4 & Skin (11 lesions) & Relapse after BMT, BM (-) & del(1)(p32p36), t(10;11)(p13;q13) \\
\hline 12 & 44 & $\mathrm{~F}$ & CML & Right breast & $\begin{array}{l}\text { CML in blast crisis receiving BMT. relapse after BMT, } \\
\text { BM (-) }\end{array}$ & Normal \\
\hline 13 & 75 & $\mathrm{~F}$ & AML-M2 & Skin & Found at initial presentation with BM (+) & $\operatorname{del}(15)(q 22 q 35)$ \\
\hline 14 & 29 & $\mathrm{~F}$ & AML-M2 & Pituitary gland & Relapse after BMT, BM (-) & Normal \\
\hline \multirow[t]{2}{*}{15} & 32 & $\mathrm{~F}$ & AML-M1 & Right breast & Relapse after BMT, BM (-) & Normal \\
\hline & & & & Left breast & Relapse after BMT, BM (-) & \\
\hline \multirow[t]{2}{*}{16} & 47 & M & AML-M1 & Brain & Relapse after chemotherapy, BM also (+) & Normal \\
\hline & & & & Spinal cord & Relapse after chemotherapy, BM also (+) & \\
\hline 17 & 47 & $\mathrm{~F}$ & AML-M2 & Skin & Relapse after chemotherapy, BM also (+) & $\mathrm{t}(8 ; 21)$ \\
\hline 18 & 40 & M & AML-M5 & Skin & $\begin{array}{l}\text { Emerging during chemotherapy and persistent after } \\
\text { BMT, BM }(+)\end{array}$ & $\begin{array}{l}-3 p, t(5 ; 17)(q 15 ; q 22), t(11 ; 19)(q 23 ; p 13),-17,19 p ; \operatorname{der}(19) t(17 ; 19)(q 11 ; p 11), \\
t(11 ; 12)(p 15 ; q 13), \operatorname{NPM}(-), \text { FLT3(-) }\end{array}$ \\
\hline 19 & 42 & $\mathrm{~F}$ & AML-M1 & Right inguinal area & Found at initial presentation with BM (+) & Normal \\
\hline \multirow[t]{3}{*}{20} & 4 & M & AML-M2 & Bone (left tibia) & Relapse after BMT, BM also (+) & $\mathrm{t}(8 ; 21), \mathrm{AML} 1-\mathrm{ETO}$ fusion transcription (+) \\
\hline & & & & Left buccal mucosa & Relapse after BMT, BM also (+) & \\
\hline & & & & Bone (right foot) & Relapse after BMT, BM also (+) & \\
\hline
\end{tabular}


transformation in one (5\%) patient, and de novo MS in one (5\%) patient. Of the 14 AML patients, $6(42.9 \%)$ were French-American-British (FAB) M2, 5 (35.7\%) were FAB M1, $2(14.3 \%)$ were FAB M4, and one (7.1\%) was FAB M5. The irradiated lesions in the 20 patients included $23(53.5 \%)$ skin, 4 (9.3\%) breast, 4 (9.3\%) brain parenchyma, 3 (7\%) spinal cord, and $3(7 \%)$ bone lesions, plus one $(2.3 \%)$ anal, one $(2.3 \%)$ cervical, one $(2.3 \%)$ pituitary, one $(2.3 \%)$ paranasal sinus, one $(2.3 \%)$ buccal mucosal, and one (2.3\%) nipple lesion.

In our study, most irradiated MS lesions (17 lesions, $39.5 \%$ ) were from patients with extramedullary relapse following BMT, and 10 (23.3\%) lesions were from patients with BM relapse accompanied by extramedullary relapse. Seven $(16.3 \%)$ lesions emerged following chemotherapy for underlying BM disease. Three $(7 \%)$ lesions presented at diagnosis of hematological malignancy with $\mathrm{BM}$ involvement, 3 (7\%) lesions presented during CML blast crisis, one (2.3\%) lesion emerged during induction/ consolidation chemotherapy and was persistent after BMT with positive BM disease, and one $(2.3 \%)$ lesion presented as de novo sarcoma as the sole site without underlying BM disease. Of the 20 patients, $10(50 \%)$ had normal cytogenetics and $10(50 \%)$ displayed abnormal chromosomes, among which $\mathrm{t}(8 ; 21)(\mathrm{q} 22 ; \mathrm{q} 22)$ was the most common abnormality (in 3 (30\%) of 10 patients).
Other observed abnormal cytogenetics included $\mathrm{t}(2 ; 14), \mathrm{t}$ $(9 ; 22)$, and del(15)(q22q35). Three patients displayed other chromosome complex changes: $\operatorname{del}(1)(\mathrm{p} 32 \mathrm{p} 36), \mathrm{t}$ $(10 ; 11)(\mathrm{p} 13 ; \mathrm{q} 13)$ in one patient, $-3 \mathrm{p}, \mathrm{t}(5: 17)(\mathrm{q} 15 ; \mathrm{q} 22)$, $\mathrm{t}(11: 19)(\mathrm{q} 23 ; \mathrm{p} 13),-17,+19 \mathrm{p} ; \operatorname{der}(19) \mathrm{t}(17 ; 19)(\mathrm{q} 11 ; \mathrm{p} 11)$, $\mathrm{t}(11 ; 12)(\mathrm{p} 15 ; \mathrm{q} 13)$ in one patient, and $47 \mathrm{XXY}$ with inv (11) in one patient.

Of the 20 patients, 9 survived and 11 died. The median survival time following RT was 6 months (range, 0.5-57 month) in all patients and 6.7 months (range, 257 month) in the surviving patients. The post-RT 1-year OS was $24 \%$ (Figure 1).

\section{Correlations between RT responses and clinical characteristics}

When evaluating the RT responses of the 20 patients with MS, we identified 13 patients (65\%) with CR, 5 (25\%) with PR, and 2 (10\%) with SD. Totally, 19 (95\%) of 20 patients achieved symptoms relief of MS after RT, except one patient with SD had persistent symptoms. Among patients with symptoms relief, 6 patients achieved symptoms relief during the treatment and 13 patients achieved symptoms relief within 3 months after completion of RT. Table 2 displays the correlations between the patients' RT responses and their clinical characteristics. The rate of CR after RT and BED2 ( $\geq 22$ Gy vs. $<22$ Gy),

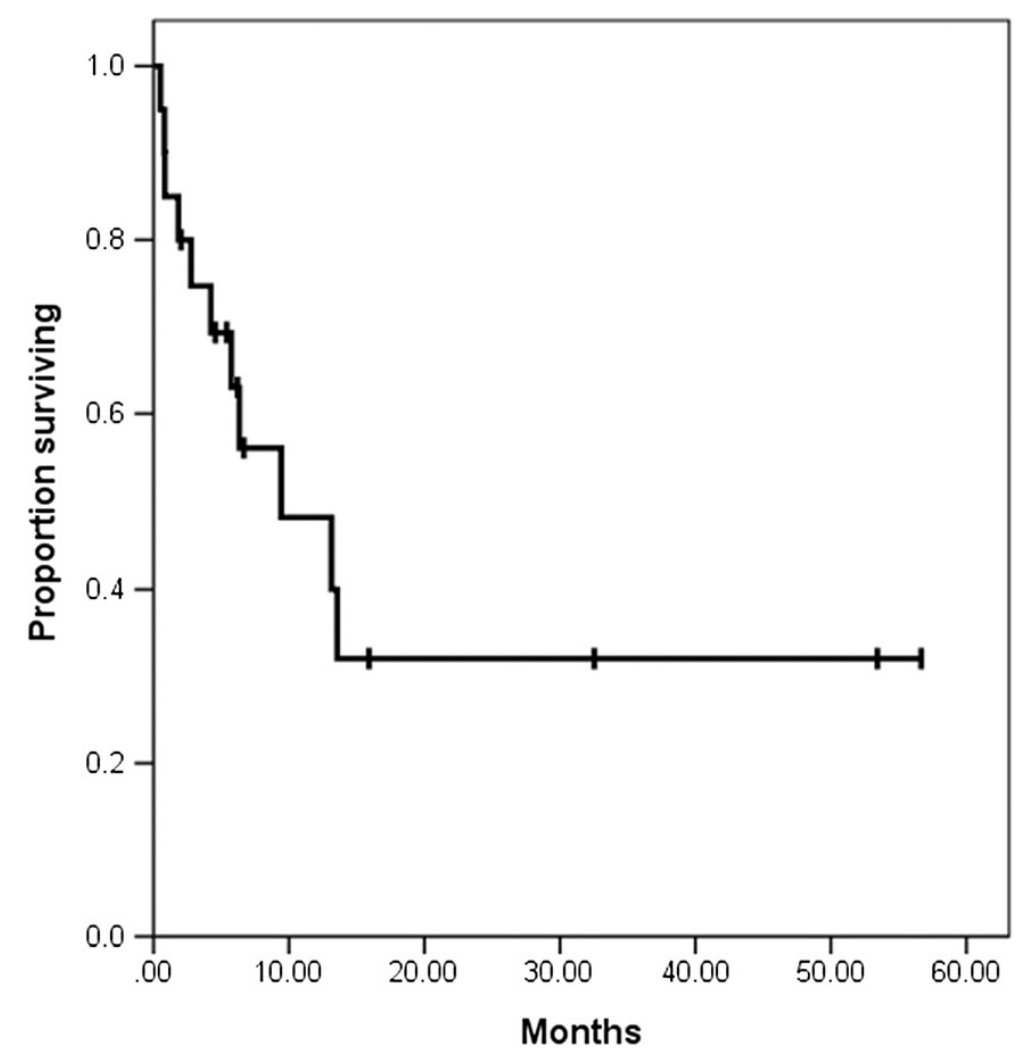

Figure 1 Kaplan-Meier overall survival curve for patients who received RT (radiotherapy) for MS (post RT survival rate). 
Table 2 Predictive factors associated with clinical CR to radiotherapy $(n=20)$

\begin{tabular}{|c|c|c|c|c|c|c|}
\hline Characteristics & $\begin{array}{l}\text { Complete response } \\
\text { (No. of patients) }\end{array}$ & $\begin{array}{l}\text { Partial response and stable } \\
\text { disease (No. of patients) }\end{array}$ & $\begin{array}{l}\text { Complete } \\
\text { response rate }\end{array}$ & $\begin{array}{l}\text { Crude odds } \\
\text { ratio }\end{array}$ & $\begin{array}{l}95 \% \text { Confidence } \\
\text { interval }\end{array}$ & $P$-value* \\
\hline \multicolumn{7}{|l|}{ BED dose } \\
\hline$\geq 22$ Gy & 3 & 4 & $43 \%$ & 4.44 & $0.62-32.07$ & 0.14 \\
\hline$<22$ Gy & 10 & 3 & $77 \%$ & 1 (Referent) & & \\
\hline \multicolumn{7}{|c|}{ Underlying disease } \\
\hline Non-AML & 3 & 4 & $43 \%$ & 4.44 & $0.62-32.07$ & 0.17 \\
\hline AML & 10 & 3 & $77 \%$ & 1 (Referent) & & \\
\hline \multicolumn{7}{|l|}{ Age } \\
\hline$\geq 50 y$ & 3 & 5 & $37.5 \%$ & 8.33 & $1.03-67.14$ & 0.06 \\
\hline$<50 y$ & 10 & 2 & $83.3 \%$ & 1 (Referent) & & \\
\hline \multicolumn{7}{|l|}{ Gender } \\
\hline Female & 5 & 4 & $55.6 \%$ & 2.13 & $0.33-13.81$ & 0.64 \\
\hline Male & 8 & 3 & $72.7 \%$ & 1 (Referent) & & \\
\hline \multicolumn{7}{|l|}{ Cytogenetics } \\
\hline Abnormal & 6 & 4 & $60 \%$ & 1.56 & $0.24-9.91$ & 1 \\
\hline Normal & 7 & 3 & $70 \%$ & 1 (Referent) & & \\
\hline \multicolumn{7}{|c|}{ Previous BMT before RT } \\
\hline Yes & 6 & 0 & $100 \%$ & NA & NA & 0.05 \\
\hline No & 7 & 7 & $50 \%$ & 1 (Referent) & & \\
\hline \multicolumn{7}{|c|}{ BM involvement at GS RT } \\
\hline Yes & 8 & 5 & $61.5 \%$ & 1.56 & $0.22-11.37$ & 1 \\
\hline No & 5 & 2 & $71 \%$ & 1 (Referent) & & \\
\hline
\end{tabular}

Abbreviations: $\mathrm{CR}$, complete remission; $\mathrm{PR}$, partial response; $\mathrm{SD}$, stable disease, BMT, bone marrow transplant; $\mathrm{RT}$, radiotherapy; $\mathrm{BM}$, bone marrow.

*Fisher's exact test.

underlying hematologic diseases (non-AML vs AML), sex, cytogenetics (normal vs abnormal), and BM status at the time of RT for MS (BM relapse vs BM remission) showed no significant correlations. Patients younger than 50 years of age had a marginally higher CR rate than those aged 50 years or older $(83.3 \%$ vs. $37.6 \%, P=0.06)$. Similarly, patients receiving $\mathrm{BMT}$ prior to $\mathrm{RT}$ had a marginally higher CR rate that those without previous BMT (100\% vs. $50 \%$, $P=0.05)$.

When using the GEE model to analyze all 43 irradiated lesions, we observed that BED2, age, sex, cytogenetics, and bone marrow status at the time of RT for MS showed no significant associations with CR (Table 3). Patients with AML had a trend toward higher CR rate than those with non-AML (OR $=5.436,95 \% \mathrm{CI}=0.999$ 29.578, $P=0.05)$. According to the logistic regression model, BMT prior to RT was also associated with marginally significant increased rate of $\mathrm{CR}$ following $\mathrm{RT}$ $(\mathrm{OR}=0.099,95 \% \mathrm{CI}=0.0086-1.135, P=0.06)$.

\section{Clinicopathologic features and survival of MS patients without RT}

Eighteen MS patients without RT served as control group. There were 10 (55.6\%) men and 8 (44.4\%) women with a median age of 17 years (range, 1-70 years) at diagnosis. The underlying hematologic diseases included AML in 14 (77.8\%) patients, CML in 4 (22.2\%) patients. The MS lesions included 5 (27.8\%) skin, $4(22.2 \%)$ bone, $2(11.1 \%)$ orbital cavity, 1 (5.6\%) brain, 1 (5.6\%) breast, 1 (5.6\%) cervix, 1 (5.6\%) neck lymph node, 1 (5.6\%) oral cavity, 1 (5.6\%) ovary, and 1 (5.6\%) uterus. Of the 18 patients, 9 (50\%) had normal cytogenetics and 9 (50\%) displayed abnormal chromosomes, among which $\mathrm{t}(9 ; 22)$ (in $4(22.2 \%)$ of 9 patients) and $t(8 ; 21)(q 22 ; q 22)$ (in $2(11.1 \%)$ of 9 patients) were the common abnormality. Other observed abnormal cytogenetics included: $t(9 ; 11)$ in one patient, $\operatorname{inv}(7)(q 22 q 36)$ in one patient, and $\operatorname{del}(7)(\mathrm{q} 32 \mathrm{q} 36), \operatorname{del}(18)(\mathrm{q} 21 \mathrm{q} 23)$ in the other patient.

Treatments consisted of surgery alone in 1 (5.6\%) patient, chemotherapy alone in $12(66.4 \%)$ patients, a combination of surgery and chemotherapy in 2 (11.2\%) patients, and bone marrow transplantation in 3 (16.8\%) patients. CR was achieved in 16 (88.9\%) of 18 patients and symptom relief was obtained in 17 (94.4\%) of 18 patients. Of the 18 patients, 6 survived and 12 died. The median survival time was 8.5 months (range, 180 month) in all patients and 20.5 months (range, 6- 
Table 3 Predictive factors associated with clinical complete remission to radiotherapy (43 lesions analyzed using the GEE model)

\begin{tabular}{|c|c|c|c|c|c|c|}
\hline Characteristics & $\begin{array}{l}\text { Complete response } \\
\text { (No. of patients) }\end{array}$ & $\begin{array}{l}\text { Partial response and stable } \\
\text { disease (No. of patients) }\end{array}$ & $\begin{array}{l}\text { Complete } \\
\text { response rate }\end{array}$ & $\begin{array}{l}\text { Univariate } \\
\text { odds ratio }\end{array}$ & $\begin{array}{l}95 \% \text { Confidence } \\
\text { interval }\end{array}$ & $P$-value \\
\hline \multicolumn{7}{|l|}{ BED dose } \\
\hline$\geq 22 \mathrm{~Gy}$ & 6 & 4 & $60 \%$ & 1.15 & $0.20-6.63$ & 0.88 \\
\hline$<22 \mathrm{~Gy}$ & 21 & 12 & $63.64 \%$ & 1 (Referent) & & \\
\hline \multicolumn{7}{|c|}{ Underlying disease } \\
\hline Non-AML & 3 & 6 & $33.33 \%$ & 5.436 & $0.999-29.578$ & 0.050 \\
\hline AML & 24 & 10 & $70.59 \%$ & 1 (Referent) & & \\
\hline \multicolumn{7}{|l|}{ Age } \\
\hline$\geq 50 y$ & 9 & 5 & $64.29 \%$ & 2.92 & $0.47-18.14$ & 0.25 \\
\hline$<50$ y & 18 & 11 & $62.07 \%$ & 1 (Referent) & & \\
\hline \multicolumn{7}{|l|}{ Gender } \\
\hline Female & 7 & 5 & $58.33 \%$ & 1.41 & $0.31-6.36$ & 0.65 \\
\hline Male & 20 & 11 & $64.52 \%$ & 1 (Referent) & & \\
\hline \multicolumn{7}{|l|}{ Cytogenetics } \\
\hline Abnormal & 13 & 10 & $56.52 \%$ & 1.35 & $0.27-6.83$ & 0.72 \\
\hline Normal & 14 & 6 & $70 \%$ & 1 (Referent) & & \\
\hline \multicolumn{7}{|c|}{ Previous BMT before RT } \\
\hline Yes & 16 & 2 & $88.89 \%$ & 0.10 & $0.01-1.14$ & 0.06 \\
\hline No & 11 & 14 & $44 \%$ & 1 (Referent) & & \\
\hline \multicolumn{7}{|c|}{ BM involvement at GS RT } \\
\hline Yes & 16 & 8 & $66.67 \%$ & 1.51 & $0.23-9.82$ & 0.67 \\
\hline No & 11 & 8 & $57.89 \%$ & 1 (Referent) & & \\
\hline
\end{tabular}

Abbreviations: $\mathrm{CR}$, complete remission; PR, partial response; SD, stable disease; RT, radiotherapy; BMT, bone marrow transplant; $\mathrm{BM}$, bone marrow.

80 month) in the surviving patients. The 1-year OS was $47.1 \%$.

\section{Discussion}

In this study, we evaluated clinicopathological features and treatment factors and their associations with RT responses in 20 patients with MS (in 43 RT courses), and also summarizes the clinicopathological features, cytogenetics, involved sites of MS, timing of RT, RT doses and fractions, and RT responses in published case reports (summarized in Table 4). Although our patients showed similar clinicopathologic features to those previously reported, we identified other diversified sites of MS involvement, including the breast [9-11], brain and spinal cord [12-15], cervix [16-19], paranasal sinus [20,21], and oral cavity [22,23]. We also observed previously unreported sites of involvement such as the nipple in men and the pituitary. Although the mechanism of MS formation is not fully understood, the leukemic cells homing to specific sites might be related to blast neural cell adhesion molecules (CD56) [2]. For example, high neural cell adhesion molecule expression in breast, testicular, ovarian, and gut tissue could explain these specific regions being common sites of MS involvement [24].
In our cytogenetically abnormal patients, $\mathrm{t}(8 ; 21)$ (q22; q22) was the most common cytogenetic change [48]. Limited previous reports exist on our identified cytogenetic abnormalities of $\mathrm{t}(2 ; 14), \mathrm{t}(9 ; 22)$, and $\operatorname{del}(15)$ (q22q35) [11]. Systemic treatment outcome might be distinct among different cytogenetic groups. For example, in the study by Rollig et al., patients with $\mathrm{t}(8 ; 21)(\mathrm{q} 22 ; \mathrm{q} 22)$ had good outcome following systemic treatment [49]. In our study, most patients had underlying AML disease. Of the non-AML patients, most had CML and a few had de novo sarcoma and MDS. In GEE analysis, we observed a trend that AML patients displayed higher $\mathrm{CR}$ rates than non-AML patients, which suggested that the underlying tumor behavior and biology of MS resulting from underlying diseases might differ. Further investigation to evaluate the radiobiological effects and elucidate the differential radiosensitivities of MS resulting from each underlying hematologic disease is warranted.

Another of our study findings was that BMT prior to RT resulted in marginally significant improvement of the $\mathrm{CR}$ rate in MS patients; however, the precise mechanism for the differential effects of RT on MS pre- and postBMT are not well-understood. The incidence of patients developing MS after BMT is reportedly 0.2\%-3.7\% 
Table 4 Published case reports on radiotherapy for GS

\begin{tabular}{|c|c|c|c|c|c|c|c|c|}
\hline Study & $\begin{array}{l}\text { Patient } \\
\text { no. }\end{array}$ & Age & Cytogenetics & Underlying disease & $\begin{array}{l}\text { Timing of GS } \\
\text { emergence }\end{array}$ & Radiotherapy site & $\begin{array}{l}\text { Dose } \\
\text { fractionation }\end{array}$ & Response \\
\hline Lee et al. [25] & 1 & 50 & $\mathrm{t}(9 ; 22)(\mathrm{q} 34 ; \mathrm{q} 11)$ & CML & Relapse after BMT, BM (-) & Clavicle and manubrium & 15 Gy & $C R$ \\
\hline Taverna et al. [26] & 1 & 62 & - & AML-M4 & $\begin{array}{l}\text { Relapse after } \\
\text { chemotherapy, BM also } \\
(+)\end{array}$ & $\begin{array}{l}\text { Left gluteal and the } \\
\text { deeper pelvic muscles }\end{array}$ & $20 \mathrm{~Gy} / 10 \mathrm{fx}$ & $P R$ \\
\hline Au et al. [27] & 1 & 24 & $\operatorname{del}(5)(q 13 ; q 33)$ & AML-MO & Relapse after BMT, BM (-) & Left breast & 30 Gy & PD \\
\hline Pulsoni et al. [28] & 1 & 84 & - & De novo sarcoma & At presentation, BM (-) & Skin & $90 \mathrm{~Gy} / 8 \mathrm{fx}$ & $C R$ \\
\hline Kasahara et al. [29] & 1 & 47 & $\operatorname{der}(1 ; 7)(q 10 ; p 10)$ & $\begin{array}{l}\text { Idiopathic myelofibrosis } \\
\text { and de novo sarcoma }\end{array}$ & At presentation, BM (-) & $\begin{array}{l}\text { Right submandibular } \\
\text { tumor }\end{array}$ & 30 Gy & $C R$ \\
\hline Buckland et al. [30] & 1 & 35 & Normal karyotype & De novo sarcoma & At presentation, BM (-) & C4-6 spine & $32 \mathrm{~Gy} / 16 \mathrm{fx}$ & $C R$ \\
\hline Lee at al. [31] & 1 & 43 & - & De novo sarcoma & At presentation, BM (-) & Maxillary gingiva & 36 Gy & $C R$ \\
\hline Fleckenstein et al. [32] & 1 & 73 & Normal karyotype & AML & $\begin{array}{l}\text { Found at initial } \\
\text { presentation with BM (+) }\end{array}$ & $\begin{array}{l}\text { Bilateral retrobulbar } \\
\text { tumor }\end{array}$ & $30 \mathrm{~Gy} / 15 f x$ & $C R$ \\
\hline Cozzi et al. [33] & 1 & 39 & Philadelphia positive & CML & Chronic phase & Left shoulder & 21 Gy & PD \\
\hline Nishimura et al. [34] & 1 & 30 & $\begin{array}{l}\operatorname{Add}(3)(q 27), t(8 ; 21)(q 22, \\
q 22)\end{array}$ & AML-M2 & Relapse after BMT, BM (-) & $\begin{array}{l}\text { Right frontal intra/ } \\
\text { extracranial tumor }\end{array}$ & 16 Gy & $C R$ \\
\hline Pelosini et al. [35] & 1 & 25 & $\begin{array}{l}\mathrm{t}(8,21) \text { with AML1-ETO } \\
\text { expression. }\end{array}$ & AML-M0 & Relapse after BMT, BM (-) & Left leg & 40 Gy & $C R$ \\
\hline Rosenberg et al. [36] & 1 & 8 & $\begin{array}{l}\text { del(7)(q22;q36),t(7;11)(p15; } \\
\text { p15) }\end{array}$ & AML-M2 & $\begin{array}{l}\text { Relapse after BMT, BM } \\
\text { also }(+)\end{array}$ & $\begin{array}{l}\text { Bilateral synchronous } \\
\text { epibulbar tumor }\end{array}$ & $24 \mathrm{~Gy} / 12 \mathrm{fx}$ & $C R$ \\
\hline Pitz et al. [37] & 1 & 50 & Normal karyotype & AML & $\begin{array}{l}\text { Relapse after } \\
\text { chemotherapy, BM also } \\
(+)\end{array}$ & Uterus/ endometrium & $30 \mathrm{~Gy} / 10 \mathrm{fx}$ & $C R$ \\
\hline Kumar et al. [38] & 1 & 10 & - & De novo sarcoma & At presentation, BM (-) & Left orbit & $24 \mathrm{~Gy} / 12 \mathrm{fx}$ & CR \\
\hline Vassiliou et al. [39] & 1 & 40 & - & De novo sarcoma & At presentation, BM (-) & Mediastinal lymph node & 41.4 Gy/23fx & $C R$ \\
\hline Kozelj et al. [40] & 1 & 52 & $\mathrm{t}(8 ; 21)$ & AML & At presentation, BM (+) & Heart & $15 \mathrm{~Gy} / 10 \mathrm{fx}$ & $C R$ \\
\hline Lee et al. [41] & 1 & 25 & $\begin{array}{l}45, X,-Y, \text { del }(2)(q 21 \mathrm{q} 31), \mathrm{t} \\
(5 ; 11)(\mathrm{q} 31 ; \mathrm{q} 13), \mathrm{t}(8 ; 21)(\mathrm{q} 22 ; \\
\mathrm{q} 22), \mathrm{t}(10 ; 19)(\mathrm{q} 22 ; \mathrm{q} 13.1)\end{array}$ & De novo sarcoma & At presentation, BM (-) & Orbit & 70 Gy & PR \\
\hline Mauermann et al. [42] & 1 & 70 & Normal karyotype & De novo sarcoma & At presentation, BM (-) & $\begin{array}{l}\text { Base of the skull to the } \\
\text { upper thoracic region, } \\
\text { including the brachial } \\
\text { plexus }\end{array}$ & $20 \mathrm{~Gy} / 10 f x$ & Good PR \\
\hline Verra et al. [43] & 1 & 45 & $\operatorname{inv}(16)$ & AML-M4 & Relapse after BMT, BM (-) & L4 to S3 spine & $21 \mathrm{~Gy} / 7 \mathrm{fx}$ & PR \\
\hline Antic et al. [44] & 1 & 24 & Normal karyotype & De novo sarcoma & At presentation, BM (-) & Lumbosacral spine & $40 \mathrm{~Gy} / 20 f x$ & $C R$ \\
\hline \multirow[t]{2}{*}{ Mignano et al. [45] } & 1 & 20 & - & AML-M2 & Relapse after BMT, BM (-) & Left jaw & $30 \mathrm{~Gy} / 15 \mathrm{fx}$ & $C R$ \\
\hline & & & & & & Heart & $24 \mathrm{~Gy} / 12 \mathrm{fx}$ & $C R$ \\
\hline Kim et al. [16] & 1 & 30 & - & De novo sarcoma & At presentation, BM (-) & Uterus/cervix & $30 \mathrm{~Gy}$ & $C R$ \\
\hline
\end{tabular}


Table 4 Published case reports on radiotherapy for GS (Continued)

\begin{tabular}{|c|c|c|c|c|c|c|c|c|}
\hline Alvarez et al. [46] & 1 & 41 & $\begin{array}{l}\text { CBFB/MYH11 fusion and } \\
\text { inv(16) (p13q22) }\end{array}$ & AML-M2 & $\begin{array}{l}\text { At initial presentation, BM } \\
\text { also }(+)\end{array}$ & $\begin{array}{l}\text { Small bowel, greater } \\
\text { omentum and } \\
\text { peritoneum }\end{array}$ & $22.4 \mathrm{~Gy} / 14 \mathrm{fx}$ & $C R$ \\
\hline Masetti et al. [47] & 1 & 11 & $\begin{array}{l}11 \mathrm{q} 23 \text { rearrangement } \\
\text { (MLL-AF10) }\end{array}$ & AML-M5 & $\begin{array}{l}\text { In remission after } \\
\text { allogeneic hematopoietic } \\
\text { stem cell transplantation, } \\
\text { BM (-) }\end{array}$ & L1 to S3 Epidural mass & $20 \mathrm{~Gy} / 16 \mathrm{fx}$ & $\begin{array}{l}\text { Good PR at the } \\
\text { end of RT }\end{array}$ \\
\hline Chak et al. [5] & $\begin{array}{l}33(54 \\
\text { courses of } \\
\text { radiotherapy) }\end{array}$ & $1.5-81$ & - & $\begin{array}{l}28(84.8 \%) \text { acute non- } \\
\text { lymphocytic leukemia, } 11 \\
(15.2 \%) \text { chronic leukiemia }\end{array}$ & - & $\begin{array}{l}33 \% \text { bone, } 31 \% \text { soft } \\
\text { tissue, } 11 \% \text { lymph node, } \\
7 \% \text { spinal cord, } 6 \% \text { brain, } \\
11 \% \text { other sites } \\
\text { (Mediastinal mass, } 2 \text {; } \\
\text { pelvic mass, } 1 \text {; pleural } \\
\text { mass, } 1 \text {; spleen, } 1 \text {; porta } \\
\text { hepatis, I) }\end{array}$ & & $\begin{array}{l}<1000 \mathrm{rad}, \mathrm{CR} \\
18 \%, 1000- \\
1999 \mathrm{rad}, \mathrm{CR} 43 \% ; \\
2000-2900 \mathrm{rad}, \mathrm{CR} \\
86 \% ;>3000 \mathrm{rad}, \\
\text { CR } 89 \%\end{array}$ \\
\hline Bakst et al. [9] & $\begin{array}{l}22 \text { ( } 33 \text { courses } \\
\text { of radiotherapy) }\end{array}$ & $\begin{array}{l}\text { Median } 34 \\
(1-71)\end{array}$ & - & $\begin{array}{l}\text { AML } 19(86 \%), \text { MDS } 2 \\
(9 \%), \text { Isolated Chloroma } \\
1(5 \%)\end{array}$ & $\begin{array}{l}32 \% \text { in remission ( } 43 \% \text { of } \\
\text { them have GS } \\
\text { concomitantly with } \\
\text { marrow relapse) }\end{array}$ & $\begin{array}{l}39 \% \text { head and neck, } 24 \% \\
\text { extremity, } 9 \% \text { spine, } 9 \% \\
\text { brain, } 6 \% \text { genito-urinary, } \\
6 \% \text { breast, } 3 \% \text { pelvis, and } \\
3 \% \text { genitourinary }\end{array}$ & $\begin{array}{l}\text { Median } 20 \\
(6-36) \mathrm{Gy} / \\
2 \mathrm{~Gy}(1.5- \\
4 \mathrm{~Gy})\end{array}$ & CR 97\% \\
\hline
\end{tabular}


[50-52]. Myeloablative conditioning regimens of BMT often include high-dose busulfan/cyclophosphamide or cyclophosphamide in combination with total body irradiation. In allogeneic BMT, graft versus host interaction is an important factor in determining the success or toxicity of the transplant. Preclinical studies have demonstrated that radiation is involved in the recruitment of effector CD8+ $\mathrm{T}$ cells to nonlymphoid tissues and this effect enhances the graft-versus-leukemia (GVL) effect after allogeneic transplantation [53,54]. These findings may explain that the more favorable response of MS toward RT after bone marrow transplant might be resulted from RT-inducing GVL effect. The influences of marked immununological disturbance during transplantation and graft versus host/leukemia interaction on the effects of RT (which is highly dependent on immunological interactions among the tumor, normal cells, and tumor microenvironment) warrant further investigation.

Age is considered a prognostic factor in AML. In our study, patients younger than 50 years of age had a trend toward higher $\mathrm{CR}$ rates following RT than those aged 50 years or older $(83.3 \%$ vs $37.6 \%, P=0.06)$. Kantarjian et al. reported reduced anthracycline sensitivity and Ras, Src, and tumor necrosis factor pathway activation in older patients with AML [55]. These deregulated signaling pathway variations may explain the poor response to RT in older patients with MS.

Although RT generally yields high CR rate, the optimal dose for MS has yet to be determined. Chak et al. [5] investigated the relationship between RT dose and response in 33 MS patients (54 RT courses), observing that the CR rate was closely associated with RT dose (CR rate: <10 Gy, 18\%; 10-19.99 Gy, 43\%; 20-29.99 Gy, $86 \%$; $>30 \mathrm{~Gy}, 89 \%)$. In their study on 22 patients with MS (33 RT courses) who received a median dose of $20 \mathrm{~Gy}$ (range 6-36 Gy) in fractions of 1.5-4 Gy, Bakst et al. showed that RT resulted in excellent disease control and minimal morbidity [9]. The authors recommended a lowdose regimen of 24 Gy in 12 fractions to irradiate MS. Our findings are consistent with the two mentioned large series reports, and demonstrate excellent local control in our 20 MS patients (43 RT courses), who received a median dose of 20 Gy (range 6-35 Gy) in fractions of 1.53.5 Gy. Although our results indicated that BED2 had nonsignificant effects on CR rate ( $\geq 22$ Gy vs $<22$ Gy), most previous cases series have reported good local control of MS in low to moderate RT doses between $20 \mathrm{~Gy}$ and 30 Gy (Table 4). The main mechanism of radiation damage to leukemic cells is apoptosis. For high-dose irradiation, the $\mathrm{D}_{0}$ of p53-deficient HL-60 leukemic cells is $2.2 \mathrm{~Gy}$, and the $\mathrm{D}_{0}$ of p53 wild MOLT-4 leukemic cells is 0.87 Gy [56]. According to radiobiological and clinical data, a 20-30 Gy radiation dose might be sufficient to achieve good local control for MS [57].

\section{Conclusion}

In summary, in this study, we evaluated the clinicopathological features and radiotherapeutic responses of 20 MS patients with 43 lesions, and identified unusual sites of MS presentation, including the nipple in men and the pituitary. Diversified cytogenetic abnormalities can occur in MS; however, the most common MS-associated cytogenetic change is $t(8 ; 21)$ (q22;q22). We further identified that the CR rate is optimal using moderate RT doses between 20 Gy and 30 Gy with conventional fractionation. Younger age, BMT prior to RT, and AML patients had marginally significant trend toward higher CR rate in MS.

\section{Consent}

Informed consent is waived.

\section{Competing interests}

The authors declare that they have no competing interest.

\section{Authors' contribution}

WYC, SHK and ALC contributed to the study design; WYC, WCW, KHL, JLT, THF, ALC and SHK treated patients; WYC and SHk collected clinical data; WYC, CHC, HHL and SHK were involved in data analysis and interpretation; WYC, WCW, KHL and SHK wrorte the manuscript; and all authors revised and approved the final manuscript.

\section{Acknowledgment}

The authors thank the Cancer Registry, Office of Medical Records, National Taiwan University Hospital for providing the necessary patient information. The authors thank the National Translation Medicine and Clinical Trial Resource Center and the Department of Medical Research in National Taiwan University Hospital for the statistical assistance.

\section{Grant support}

This study was supported by research grants NSC96-2321-B-002-013, NSC96-2321-B-002-014, NSC96-2314-B-002-164MY3, NSC 98-2314-B-002-087MY3, NSC 100-2321-B-002-032, and NSC 101-2314-B-002-157-MY3 from the National Science Council, Taiwan, NHRI-EX102-10239BI from the National Health Research Institutes, Taiwan, NTUH. 102-M2228 from National Taiwan University Hospital, Taiwan and DOH100-TD-B-111-001 from the Department of Health, Taiwan.

\section{Author details}

'Division of Radiation Oncology, Department of Oncology, National Taiwan University Hospital and National Taiwan University College of Medicine, Taipei, Taiwan. ²Department of Medical Research, National Taiwan University Hospital and National Taiwan University College of Medicine, Taipei, Taiwan. ${ }^{3}$ Department of Internal Medicine, National Taiwan University Hospital and National Taiwan University College of Medicine, Taipei, Taiwan. ${ }^{4}$ National Translational Medicine and Clinical Trial Resource Center, Taipei, Taiwan. ${ }^{5}$ Cancer Research Center, National Taiwan University College of Medicine, Taipei, Taiwan. ${ }^{6}$ Graduate Institute of Oncology, National Taiwan University College of Medicine, Taipei, Taiwan. ${ }^{7}$ Graduate Institute of Clinical Medicine, National Taiwan University College of Medicine, Taipei, Taiwan.

Received: 26 March 2013 Accepted: 15 October 2013

Published: 22 October 2013

\section{References}

1. Neiman RS, Barcos M, Berard C, Bonner H, Mann R, Rydell RE, Bennett JM: Granulocytic sarcoma: a clinicopathologic study of 61 biopsied cases. Cancer 1981, 48:1426-1437.

2. Byrd JC, Edenfield WJ, Shields DJ, Dawson NA: Extramedullary myeloid cell tumors in acute nonlymphocytic leukemia: a clinical review. J Clin Oncol 1995, 13:1800-1816.

3. Paydas S, Zorludemir S, Ergin M: Granulocytic sarcoma: 32 cases and review of the literature. Leuk Lymphoma 2006, 47:2527-2541. 
4. Maeng H, Cheong JW, Lee ST, Yang WI, Hahn JS, Ko YW, Min YH: Isolated extramedullary relapse of acute myelogenous leukemia as a uterine granulocytic sarcoma in an allogeneic hematopoietic stem cell transplantation recipient. Yonsei Med J 2004, 45:330-333.

5. Chak LY, Sapozink MD, Cox RS: Extramedullary lesions in non-lymphocytic leukemia: results of radiation therapy. Int J Radiat Oncol Biol Phys 1983, 9:1173-1176.

6. Barendsen GW: Dose fractionation, dose rate and iso-effect relationships for normal tissue responses. Int J Radiat Oncol Biol Phys 1982, 8:1981-1997.

7. Kal HB, Loes van Kempen-Harteveld M, Heijenbrok-Kal MH, Struikmans H: Biologically effective dose in total-body irradiation and hematopoietic stem cell transplantation. Strahlenther Onkol 2006, 182:672-679.

8. Zeger SL, Liang KY, Albert PS: Models for longitudinal data: a generalized estimating equation approach. Biometrics 1988, 44:1049-1060.

9. Bakst R, Wolden S, Yahalom J: Radiation therapy for chloroma (granulocytic sarcoma). Int J Radiat Oncol Biol Phys 2012, 82:1816-1822.

10. Cunningham I: A clinical review of breast involvement in acute leukemia. Leuk Lymphoma 2006, 47:2517-2526.

11. Azim HA Jr, Gigli F, Pruneri G, Martinelli G, Travaini LL, Petralia G, Peccatori FA: Extramedullary myeloid sarcoma of the breast. J Clin Oncol 2008, 26:4041-4043.

12. Grier DD, Al-Quran SZ, Gray B, Li Y, Braylan R: Intracranial myeloid sarcoma. Br J Haematol 2008, 142:681.

13. Passarin MG, Vattemi E, Musso AM, Romito S, Moretto G, Ghimenton C, Iuzzolino P, Doglioni C, Pedersini R: Intracranial granulocytic sarcoma after chemotherapy for pineal germinoma and testicular cancer. J Clin Oncol 2008, 26:4507-4509.

14. Akhaddar A, Zyani M, Mikdame M, Boucetta M: Acute myeloid leukemia with brain involvement (chloroma). Intern Med 2011, 20:535-536.

15. Seo HY, Kim SJ, Choi JW, Lee JB, Kang CH, Seo BK, Kim BS: Unusual relapse of acute myeloid leukemia: granulocytic sarcoma presenting as an acute paraplegia. Ann Hematol 2006, 85:196-197.

16. Kim SC, Natarajan-Ame S, Lioure B, Chenard MP, Duclos B, Herbrecht R, Bergerat JP: Successful treatment of a granulocytic sarcoma of the uterine cervix in complete remission at six-year follow-up. $J$ Oncol 2010:812424.

17. Pathak B, Bruchim I, Brisson ML, Hammouda W, Bloom C, Gotlieb WH: Granulocytic sarcoma presenting as tumors of the cervix. Gynecol Oncol 2005, 98:493-497.

18. Chiang YC, Chen $\mathrm{CH}$ : Cervical granulocytic sarcoma: report of one case and review of the literature. Eur J Gynaecol Oncol 2010, 31:697-700.

19. Ouansafi I, Arabadjief M, Mathew S, Srivastara S, Orazi A: Myeloid sarcoma with $\mathrm{t}(11 ; 19)(q 23 ; \mathrm{p} 13.3)$ (MLL-ELL) in the uterine cervix. Br J Haematol 2011, 153:679.

20. Ferri E, Minotto C, lanniello F, Cavaleri S, Armato E, Capuzzo P: Maxilloethmoidal chloroma in acute myeloid leukaemia: case report. Acta Otorhinolaryngol Ital 2005, 25:195-199.

21. Ben Hassine L, Chaouch S, Douira W, Louati H, Lahmar L, Fdhila F, Mrad K, Barsaoui S, Bellagha I: [Granulocytic sarcoma of the maxillary sinus: a pediatric case report]. Tunis Med 2011, 89:305-308.

22. Papamanthos MK, Kolokotronis AE, Skulakis HE, Fericean AM, Zorba MT, Matiakis AT: Acute myeloid leukemia diagnosed by intra-oral myeloid sarcoma. A case report. Head Neck Pathol 2010, 5:132-135.

23. Amin KS, Ehsan A, McGuff HS, Albright SC: Minimally differentiated acute myelogenous leukemia (AML-M0) granulocytic sarcoma presenting in the oral cavity. Oral Oncol 2002, 38:516-519.

24. Byrd JC, Weiss RB: Recurrent granulocytic sarcoma: an unusual variation of acute myelogenous leukemia associated with 8;21 chromosomal translocation and blast expression of the neural cell adhesion molecule. Cancer 1994, 73:2107-2112.

25. Lee JJ, Kim HJ, Kook H, Chung IJ, Seo JS, Seo KS, Hwang TJ: Granulocytic sarcoma as isolated extramedullary relapse after donor lymphocyte infusion in a patient with CML who relapsed after allogeneic bone marrow transplantation: a case report. J Korean Med Sci 1998, 13:434-436.

26. Taverna C, Vogt P, Pestalozzi BC: Uncommon sites of presentation of hematologic malignancies. Case 2: diffuse muscle infiltration by granulocytic sarcoma seven years after acute myelomonocytic leukemia. J Clin Oncol 1999, 17:1642-1643.

27. Au WY, Ma SK, Kwong YL, Lie AK, Shek WH, Chow WC, Liang R: Acute myeloid leukemia relapsing as gynecomastia. Leuk Lymphoma 1999, 36:191-194.
28. Pulsoni A, Falcucci P, Anghel G, Ribersani M, Petrucci MT, Pescarmona E, Muscardin L: Isolated granulocytic sarcoma of the skin in an elderly patient: good response to treatment with local radiotherapy and lowdose methotrexate. J Eur Acad Dermatol Venereol 2000, 14:216-218.

29. Kasahara S, Tsurumi H, Hara T, Goto H, Moriwaki H: Idiopathic myelofibrosis developing isolated granulocytic sarcoma with der (1;7)(q10; p10) after splenectomy and finally transforming to acute myelogenous leukemia. Leuk Lymphoma 2000, 39:427-433.

30. Buckland ME, Scolyer RA, Donellan MB, Brew S, McGee-Collett M, Harper CG: Spinal chloroma presenting with triplegia in an aleukaemic patient. Pathology 2001, 33:386-389.

31. Lee SS, Kim HK, Choi SC, Lee Jl: Granulocytic sarcoma occurring in the maxillary gingiva demonstrated by magnetic resonance imaging. Oral Surg Oral Med Oral Pathol Oral Radiol Endod 2001, 92:689-693.

32. Fleckenstein K, Geinitz H, Grosu A, Goetze K, Werner M, Molls M: Irradiation for conjunctival granulocytic sarcoma. Strahlenther Onkol 2003, 179:187-190.

33. Cozzi P, Nosari A, Cantoni S, Ribera S, Pungolino E, Lizzadro G, Oreste P, Asnaghi D, Morra E: Traumatic left shoulder fracture masking aggressive granuloblastic sarcoma in a CML patient. Haematologica 2004, 89:EIM15.

34. Nishimura S, Kyuma Y, Kamijo A, Maruta A: Isolated recurrence of granulocytic sarcoma manifesting as extra- and intracranial masses-case report. Neurol Med Chir (Tokyo) 2004, 44:311-316.

35. Pelosini M, Benedetti E, Galimberti S, Caracciolo F, Petrini M, Fazzi R, Andreazzoli F, Papineschi F: Granulocytic sarcoma and subsequent acute leukemia recurrence with different biologic characteristics 5 years after allogeneic bone marrow transplantation for acute myeloid leukemia. Bone Marrow Transplant 2006, 37:897-898.

36. Rosenberg C, Finger PT, Furlan L, lacob CE: Bilateral epibulbar granulocytic sarcomas: a case of an 8-year-old girl with acute myeloid leukaemia. Graefes Arch Clin Exp Ophthalmol 2007, 245:170-172.

37. Pitz MW, Maslyak O, Morales C, Seftel MD: Myeloid sarcoma of the uterus presenting as vaginal bleeding. Intern Med J 2006, 36:669-671.

38. Kumar J, Seith A, Bakhshi S, Kumar R, Kumar A, Sen S: Isolated granulocytic sarcoma of the orbit. Eur J Haematol 2007, 78:456.

39. Vassiliou V, Christopoulos C, Kardamakis D, Tinniakou M, Puglisi M, Vomvas D, Matsouka P: Isolated granulocytic sarcoma involving the mediastinum and bilateral cervical lymph nodes. Eur J Haematol 2007, 78:548.

40. Kozelj M, Zorman D, Mrevlje B, Cernelc P, Zver S: Cardiac granulocytic sarcoma diagnosed by intracardiac echocardiography-guided biopsy. Int J Hematol 2008, 88:101-103.

41. Lee SG, Park TS, Cheong JW, Yang WI, Song J, Lee KA, Kim J, Park Y, Choi JR: Preceding orbital granulocytic sarcoma in an adult patient with acute myelogenous leukemia with $t(8 ; 21)$ : a case study and review of the literature. Cancer Genet Cytogenet 2008, 185:51-54.

42. Mauermann ML, Angius D, Spinner RJ, Letendre L, Amrami KK, Dyck PJ: Isolated granulocytic sarcoma presenting as a brachial plexopathy. J Peripher Nerv Syst 2008, 13:153-156.

43. Verra WC, Snijders TJ, Seute T, Han KS, Nieuwenhuis HK, Rutten GJ: Myeloid sarcoma presenting as a recurrent, multifocal nerve root entrapment syndrome. J Neurooncol 2009, 91:59-62.

44. Antic D, Verstovsek S, Elezovic I, Grujicic D, Gotic M, Bila J, Perunicic M, Jakovic L: Spinal epidural granulocytic sarcoma in non-leukemic patient. Int J Hematol 2009, 89:95-97.

45. Mignano JE, Chan MD, Rosenwald IB, Kimmelstiel CD, Wolfe LC: Intracardiac chloroma. J Pediatr Hematol Oncol 2009, 31:977-979.

46. Alvarez P, Navascues CA, Ordieres C, Pipa M, Vega IF, Granero P, Alvarez JA, Rodriguez M: Granulocytic sarcoma of the small bowel, greater omentum and peritoneum associated with a CBFbeta/MYH11 fusion and inv(16) (p13q22): a case report. Int Arch Med 2011, 4:3.

47. Masetti R, Gasperini P, Prete A, Pession A: Granulocytic sarcoma of the knee and the spine as aleukemic relapse of acute myeloid leukemia in a child. J Pediatr Hematol Oncol 2011, 33:480-481.

48. Tallman MS, Hakimian D, Shaw JM, Lissner GS, Russell EJ, Variakojis D: Granulocytic sarcoma is associated with the 8;21 translocation in acute myeloid leukemia. J Clin Oncol 1993, 11:690-697.

49. Rollig C, Bornhauser M, Thiede C, Taube F, Kramer M, Mohr B, Aulitzky W Bodenstein H, Tischler HJ, Stughlmann R, Schuler U, Stolzel F, von Bonin M, Wandt H, Schafer-Eckart K, Schaich M, Ehninger G: Long-term prognosis of acute myeloid leukemia according to the new genetic risk classification of the European LeukemiaNet recommendations: evaluation of the proposed reporting system. J Clin Oncol 2011, 29:2758-2765. 
50. Szomor A, Passweg JR, Tichelli A, Hoffmann T, Speck B, Gratwohl A: Myeloid leukemia and myelodysplastic syndrome relapsing as granulocytic sarcoma (chloroma) after allogeneic bone marrow transplantation. Ann Hematol 1997, 75:239-241.

51. Koc Y, Miller KB, Schenkein DP, Daoust P, Sprague K, Berkman E: Extramedullary tumors of myeloid blasts in adults as a pattern of relapse following allogeneic bone marrow transplantation. Cancer 1999, 85:608-615.

52. Bekassy AN, Hermans J, Gorin NC, Gratwohl A: Granulocytic sarcoma after allogeneic bone marrow transplantation: a retrospective European multicenter survey. acute and chronic leukemia working parties of the European group for blood and marrow transplantation. Bone Marrow Transplant 1996, 17:801-808.

53. Chakraverty R, Flutter B, Fallah-Arani F, Eom HS, Means T, Andreola G, Schwarte S, Buchli J, Cotter P, Zhao G, Sykes M: The host environment regulates the function of $\mathrm{CD} 8+$ graft-versus-host-reactive effector cells. J Immunol 2008, 181:6820-6828.

54. Lim JY, Choi MS, Youn H, Choi EY, Min CK: The influence of pretransplantation conditioning on graft-vs.-leukemia effect in mice. Exp Hematol 2011, 39:1018-1029.

55. Kantarjian H, O'Brien S, Cortes J, Giles F, Faderl S, Jabbour E, Garcia-Manero G, Wierda W, Pierce S, Shan J, Estey E: Results of intensive chemotherapy in 998 patients age 65 years or older with acute myeloid leukemia or high-risk myelodysplastic syndrome: predictive prognostic models for outcome. Cancer 2006, 106:1090-1098.

56. Vavrova J, Rezacova M, Vokurkova D, Psutka J: Cell cycle alteration, apoptosis and response of leukemic cell lines to gamma radiation with high- and low-dose rate. Physiol Res 2004, 53:335-342.

57. Ozawa K, Miura Y, Suda T, Motoyoshi K, Takaku F: Radiation sensitivity of leukemic progenitor cells in acute nonlymphocytic leukemia. Cancer Res $1983,43: 2339-2341$.

doi:10.1186/1748-717X-8-245

Cite this article as: Chen et al:: Clinicopathologic features and responses to radiotherapy of myeloid sarcoma. Radiation Oncology 2013 8:245.

\section{Submit your next manuscript to BioMed Central and take full advantage of:}

- Convenient online submission

- Thorough peer review

- No space constraints or color figure charges

- Immediate publication on acceptance

- Inclusion in PubMed, CAS, Scopus and Google Scholar

- Research which is freely available for redistribution 